\title{
Aquifer Evaluation at Fenton Hill, October and November 1980
}

\author{
N. M. Becker \\ W. D. Purtymun \\ W. C. Ballance *
}

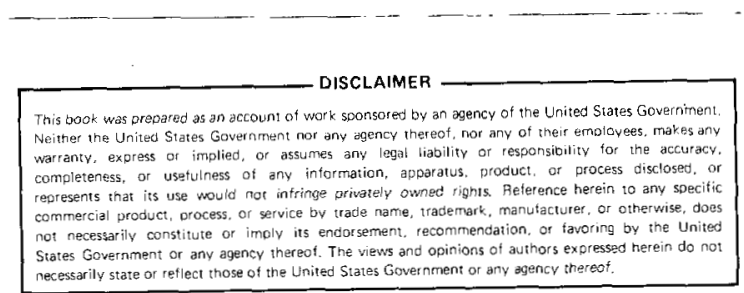

*Consultant. 179 La Cueva, Los Alamos, NM 87544.

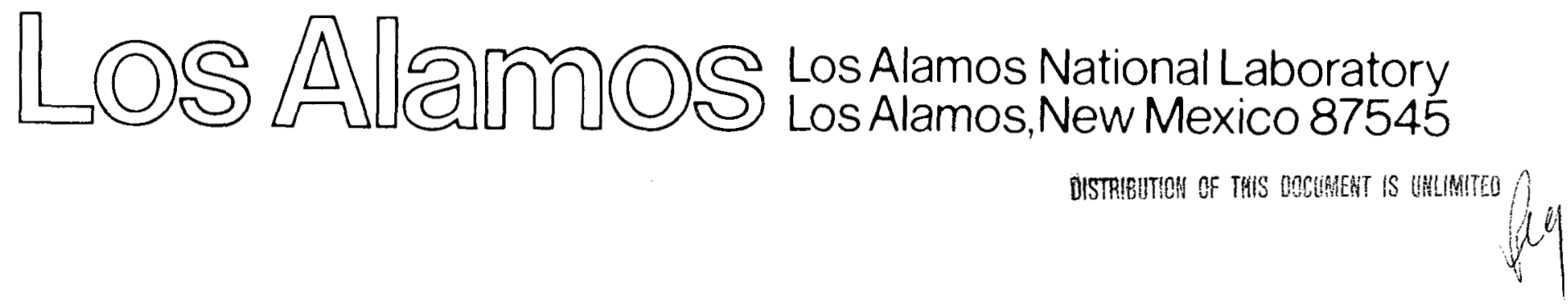




\section{DISCLAIMER}

This report was prepared as an account of work sponsored by an agency of the United States Government. Neither the United States Government nor any agency Thereof, nor any of their employees, makes any warranty, express or implied, or assumes any legal liability or responsibility for the accuracy, completeness, or usefulness of any information, apparatus, product, or process disclosed, or represents that its use would not infringe privately owned rights. Reference herein to any specific commercial product, process, or service by trade name, trademark, manufacturer, or otherwise does not necessarily constitute or imply its endorsement, recommendation, or favoring by the United States Government or any agency thereof. The views and opinions of authors expressed herein do not necessarily state or reflect those of the United States Government or any agency thereof. 


\section{DISCLAIMER}

Portions of this document may be illegible in electronic image products. Images are produced from the best available original document. 


\title{
AQUIFER EVALUATION AT FENTON HILL, OCTOBER AND NOVEMBER 1980
}

by

N. M. Becker, W. D. Purtymun, and W. C. Ballance

\begin{abstract}
An aquifer test at the Fenton Hill Geothermal Site was performed on a volcanic aquifer used for water supply. The test was made to determine the yield from the aquifer and to predict the amount of depletion that would occur with increased production during the period 1981-1985. A step-discharge test indicated the aquifer would comfortably yield $100 \mathrm{gal}$ per $\min (\mathrm{gpm})$ without excessive water level drawdown in the pumping well. Drawdown test results indicated that the average aquifer transmissivity and storage coefficient are $5000 \mathrm{gal}$ per day per foot (gpd/ft) and 0.07 , respectively. Using these parameters, a drawdown was estimated to be at least $42 \mathrm{ft}$ at the pumping well due to a withdrawal of 500 acre-ft of water over $5 \mathrm{yr}$. However, the presence of ground water boundaries indicates the aquifer is of limited extent, and because of this, the water level decline would probably be much greater. Past water level data indicate that there is little recharge to the aquifer and that the ground water is being depleted.
\end{abstract}

\section{INTRODUCTION}

The Fenton Hill Site (TA-57) of the Los Alamos National Laboratory is located about $40 \mathrm{mi}$ west of Los Alamos, New Mexico, on the western flank of the Valles Caldera, where investigations are in progress to extract heat from dry geothermal reservoirs.'

The development of the geothermal reservoir systems, drilling, fracturing to form the reservoirs, filling the reservoirs for the circulation tests, and supplying makeup water for losses incurred during circulation requires a water supply. Since late 1976, a part of the water supply has come from a well completed in the Cenozoic volcanics while the remainder has been hauled to the site. Therefore, evaluation of the volcanic aquifer was made to determine if it could furnish expected future requirements.

The evaluation consisted of a stepped-drawdown test and a 10-day constant-discharge aquifer-drawdown test and recovery in October and November 1980. The data from the step and aquifer test were used to determine hydrogeologic parameters to evaluate the performance of the aquifer with the anticipated increased production. This report presents this evaluation and also summarizes previous hydrologic studies.

Two hydrogeologic parameters that frequently will be referred to are aquifer transmissivity and storage coefficient. The transmissivity $(\mathrm{T})$, which is a measure of the ease with which the aquifer transmits water, may be defined

$\mathrm{T}=\mathrm{Kb}$

where

$\mathrm{K}=$ hydraulic conductivity

b $=$ saturated thickness 
the storage coefficient (s) may be defined<smiles>S=S</smiles>

where

$\forall_{w r}=$ volume of water released or taken into storage

$\forall_{\mathrm{a}}=$ volume of aquifer; cross sectional area under unit decline in potentiometric head.

Using a model for radial flow in an infinite, homogeneous, confined aquifer under nonequilibrium conditions, the aquifer test data were used to compute a transmissivity $\mathrm{T}$ of $5000 \mathrm{gpd} / \mathrm{ft}$ (gal per day per foot) and a storage coefficient $s$ of 0.07 (dimensionless). During the 10-day test, at least five hydrologic boundaries were present. These boundaries indicate the aquifer is of limited spatial extent. Records of water level decline indicate that there is little or no recharge to this aquifer, and that the ground water is being mined. A projection of water level decline due to the withdrawal of 500 acre. $\mathrm{ft}$ of water over $5 \mathrm{yr}$ was made using $\mathrm{T}=5000 \mathrm{gpd} / \mathrm{ft}$ and $s=0.07$; a drawdown of $41.6 \mathrm{ft}$ at FH-1 (the pumping well) and $19.4 \mathrm{ft}$ at FH-3 (located $90 \mathrm{ft}$ from FH-1) was computed. However, due to the presence of aquifer boundaries, the actual decline is expected to be greater than the computed decline.

\section{A. Geohydrology}

The Fenton Hill Site is located near the eastern end of a narrow southwest-trending mesa on the western side of the Valles Caldera. The surface of the mesa slopes gently to the southwest terminating in cliffs and steep slopes above the Rio Cebolla (Fig. 1). Lake Fork Canyon to the south drains the immediate area of the site and is tributary to the Rio Cebolla. Lake Fork Canyon contains intermittent streams in the upper reach; however, near the Rio Cebolla, the ground water discharges to form perennial streams that reach the Rio Cebolla. The eastern edge of the mesa is terminated by a canyon cut by San Antonio Creek, which drains to the south (Fig. 1).

The elevation of the site is about $8700 \mathrm{ft}$. The average annual precipitation in the area ranges from 14 in. at lower elevations to about $22 \mathrm{in}$. of precipitation in the mountains east of the site. Average annual air temperature ranges from 40 to $50^{\circ} \mathrm{F}$ with annual reservoir evaporation at about 46 in. $^{2}$

The upper surface of the mesa is formed by the Bandelier Tuff which, in turn, is underlain by the Paliza Canyon Formation and Abiquiu Tuff. ${ }^{3-6}$ The volcanic aquifer is within the Abiquiu Tuff and lower part of the Paliza Canyon Formation. The aquifer is underlain by the Abo Formation that perches the aquifer in the volcanics.'

The Bandelier Tuff is a series of ashflows of moderately welded to welded rhyolite tuff. The tuff ranges from light to dark gray and consists of quartz and sanidine crystals with crystal and lithic fragments of

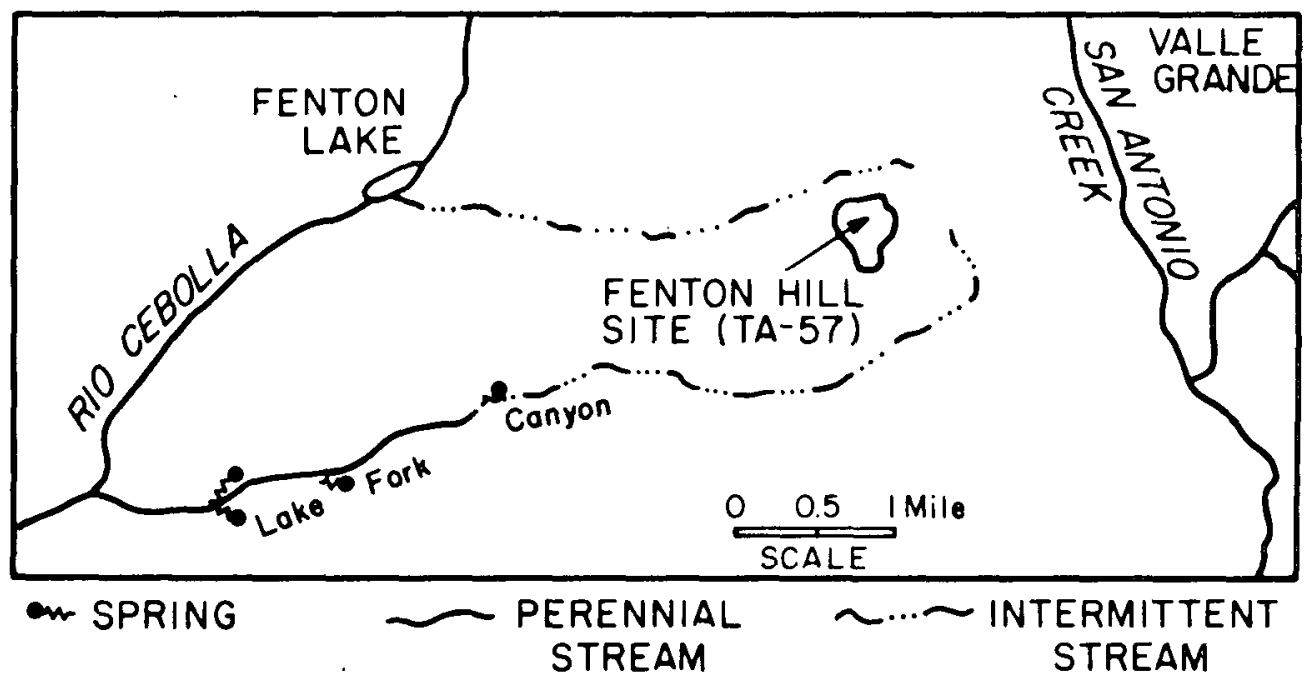

Fig. 1. Location of TA-57 on the west side of the Valle Grande. 
latite and rhyolite in an ash matrix. The thickness at the site is about $50 \mathrm{ft}$.

The Paliza Canyon Formation underlies the Bandèlier Tuff. The formation is composed of andesite and basalt andesite breccias that are interbedded with sand and gravels. The thickness at the site is about $310 \mathrm{ft}$. The Abiquiu Tuff underlies the Paliza Canyon and is composed of a light gray, friable tuffaceous sandstone. The sandstone is composed of quartz, chalcedony, and fragments of the rhyolite and quartzite in a tuffaceous matrix. The upper part of the section is interbedded with angular fragments of basalts. The lower part contains rock fragments and pebbles derived from Precambrian crystalline rocks. The thickness of the Abiquiu Tuff is about $90 \mathrm{ft}$ at the site. ${ }^{8}$

The Abo Formation underlying the Abiquiu Tuff is composed of clay, shale, siltstones, fine-grained sandstones and some thin lenses of limestone. The Abo Formation is relatively impermeable.

The upper surface of the Abo Formation has been fluted and dissected by erosion before the deposition of the volcanics. These erosional channels in the Abo, which were subsequently filled with volcanic debris, comprise the aquifer that has supplied water to the site. The amount of storage in this aquifer is determined mainly by the width and spatial extent of the channels. Topographic highs of the Abo surface limits the aquifer's thickness and lateral extent, and will "disconnect" portions of the aquifer where the Abo surface is above the saturated section.?

Generalized contours on the top of the Abo Formation in the area of Fenton Hill indicate the formation dips to the southwest at about $80 \mathrm{ft} / \mathrm{mi}$ (Fig. 2). The general movement of water is toward the southwest where a series of springs and seeps discharge from the volcanics into the middle and lower reaches of Lake Fork Canyon (Fig. 1).

The depth to the top of the aquifer at the site is about $370 \mathrm{ft}$. Water level measurements in observation wells in the immediate area of the site indicate that the water table is near flat.

\section{B. Supply, Exploratory, and Observation Wells}

The presence of water in the volcanics overlying the siltstones and shales of the Abo Formation was determined in 1974 from drilling conditions and geophysical logs of Geothermal Test Hole GT-2. ${ }^{9}$ It was recommend- ed at that time that an exploratory well be drilled and completed as a supply well if tests indicated an adequate yield.

Supply well FH-1 was completed in 1976 at a depth of $450 \mathrm{ft}$ with the water level at an elevation of $8308 \mathrm{ft}$ or about $366 \mathrm{ft}$ below land surface (see Fig. 3). The aquifer was artesian because the water rose in the well about 10 $\mathrm{ft}$ after the aquifer was perforated. The well did not penetrate the entire thickness of the aquifer (Table I).

Aquifer tests in January 1978 indicated the well had a specific capacity of about $137 \mathrm{gpm}$ (gal per min) per ft of drawdown after $122 \mathrm{~h}$ at a pumping rate of $44 \mathrm{gpm}$ (drawdown $0.32 \mathrm{ft}$ ). A second test indicated a specific capacity of $191 \mathrm{gpm}$ per $\mathrm{ft}$ of drawdown at a pumping rate of $38 \mathrm{gpm}$ after $25 \mathrm{~min}$ of pumping (drawdown 0.20 $\mathrm{ft}$ ). Based on the specific capacity, a transmissivity $(\mathrm{T})$ of the aquifer was estimated at $100000 \mathrm{gpd} / \mathrm{ft}$. The total production from the well from November 1976 through December 1980 has been $20 \times 10^{6}$ gal.

Test hole FH-2 was drilled in late December 1979 and completed with a torch-slotted 16-in. casing. The test hole encountered the Abo Formation at a depth of 433 $\mathrm{ft}$, or more than $20 \mathrm{ft}$ higher than in supply well FH-1. FH-2 was completed at a depth of $450 \mathrm{ft}$. The water level elevation was $8321 \mathrm{ft}$, or $371 \mathrm{ft}$ below land surface. A test on February 4, 1980, indicated a specific capacity of $0.8 \mathrm{gpm}$ per $\mathrm{ft}$ of drawdown at a pumping rate of $20 \mathrm{gpm}$ after $2.25 \mathrm{~h}$ of pumping (drawdown $2.5 \mathrm{ft}$ ). ${ }^{10}$ At that time, the pumping rate was increased to $40 \mathrm{gpm}$ and the water level dropped $49 \mathrm{ft}$ to the top of the pump setting. The specific capacity at the end of $40 \mathrm{~min}$ at the rate of 40 $\mathrm{gpm}$ was about $1 \mathrm{gpm}$ per $\mathrm{ft}$ of drawdown. Using the drawdown at a pümpiñing rảte of $20 \mathrm{~g}$ p calculated to be about $600 \mathrm{gpd} / \mathrm{ft}$, whereas from the water level recovery, the $\mathrm{T}$ was about $300 \mathrm{gpd} / \mathrm{ft} .{ }^{11}$ The storage coefficient was $1 \times 10^{-5}$. The poor yield at the time was attributed to the reduced thickness of the aquifer.

A third test hole, FH-3, was drilled in March 1980 near FH-1. Well FH-3, completed at a depth of $460 \mathrm{ft}$, penetrated the top of the Abo Formation. The water level was at about $373 \mathrm{ft}$ with the hole penetrating $85 \mathrm{ft}$ of the aquifer. The hole was completed using torch-cut slots in the casing. Three bailing tests were made of the aquifer to determine characteristics. These tests gave a specific capacity of less than $1 \mathrm{gpm}$ per $\mathrm{ft}$ of drawdown. ${ }^{10}$

Inspection of the wellbore with a downhole TV camera showed that the torch slots in both FH-2 and FH-3 were plugged with silt and clay. The results of the 


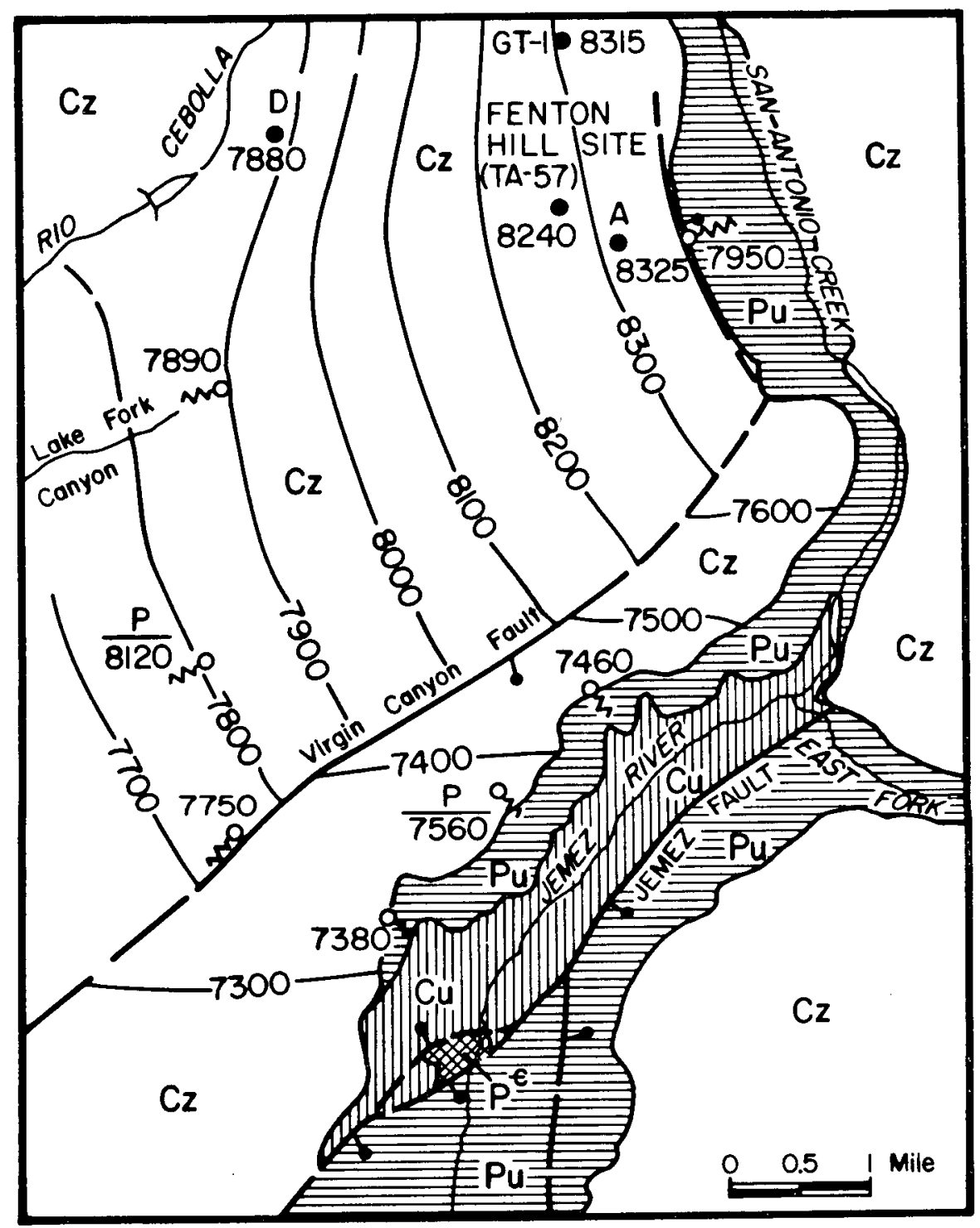

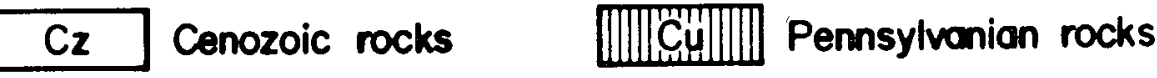

\begin{tabular}{|c|c|c|c|}
\hline$\overline{\overline{E P u}}$ & Permian rocks & 郯级 & Precambrian rocks \\
\hline & $\begin{array}{l}\text { Contours on top of } \\
\text { Permian rock (Abo) }\end{array}$ & I & $\begin{array}{l}\text { Fault; bar and bell } \\
\text { on downthrown side }\end{array}$ \\
\hline on & $\begin{array}{l}\text { Spring ot/or near } \\
\text { top of Abo; } P \text {, } \\
\text { perched in Cenozoic } \\
\text { rocks }\end{array}$ & - & Test hole \\
\hline
\end{tabular}

Fig. 2. Generalized geologic map of the Fenton Hill Site (TA-57) showing the erosional surface on top of the Abo Formation (base of the aquifer in volcanics). 


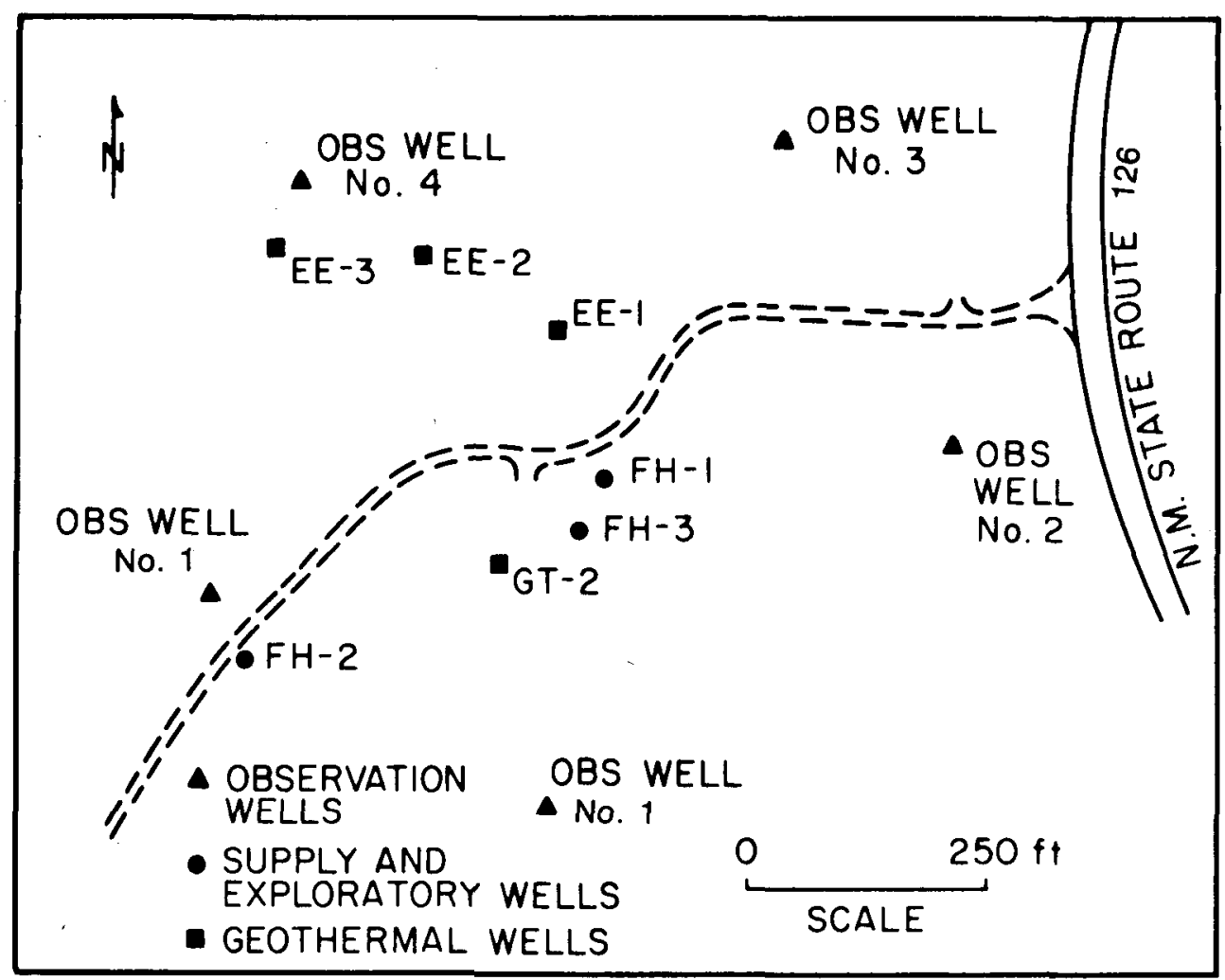

Fig. 3. Site map of Fenton Hill showing location of observation, supply, exploratory, and geothermal wells.

TABLE I

WELL CONSTRUCTION FH-1, FH-2, AND FH-3

\begin{tabular}{|c|c|c|c|}
\hline & FH-1 & FH-2 & FH-3 \\
\hline Diameter of Casing (in.) & $7^{a}$ & 16 & 16 \\
\hline Depth Cased (ft) & 450 & 450 & 460 \\
\hline Depth to Water (ft) & 372 & 371 & 373 \\
\hline Elevation of Water Surface $(\mathrm{ft})$ & 8314 & 8321 & 8319 \\
\hline Thickness of Aquifer ( $\mathrm{ft}$ ) & $78+$ & 63 & \\
\hline Length of Screen or Slots $(\mathrm{ft})$ & $60^{\mathrm{b}}$ & $59^{\mathrm{c}}$ & $9^{c}$ \\
\hline Specific Capacity $(\mathrm{gpm} / \mathrm{ft})$ & $100+$ & $\approx 1$ & 1 \\
\hline
\end{tabular}

${ }^{\text {a }}$ Set with screen on liner $5-1 / 2$ in.

bSlotted screen 0.025 -in. slots.

${ }^{\mathrm{c}}$ Torch-slotted casing.

Note: Water levels (1980). 


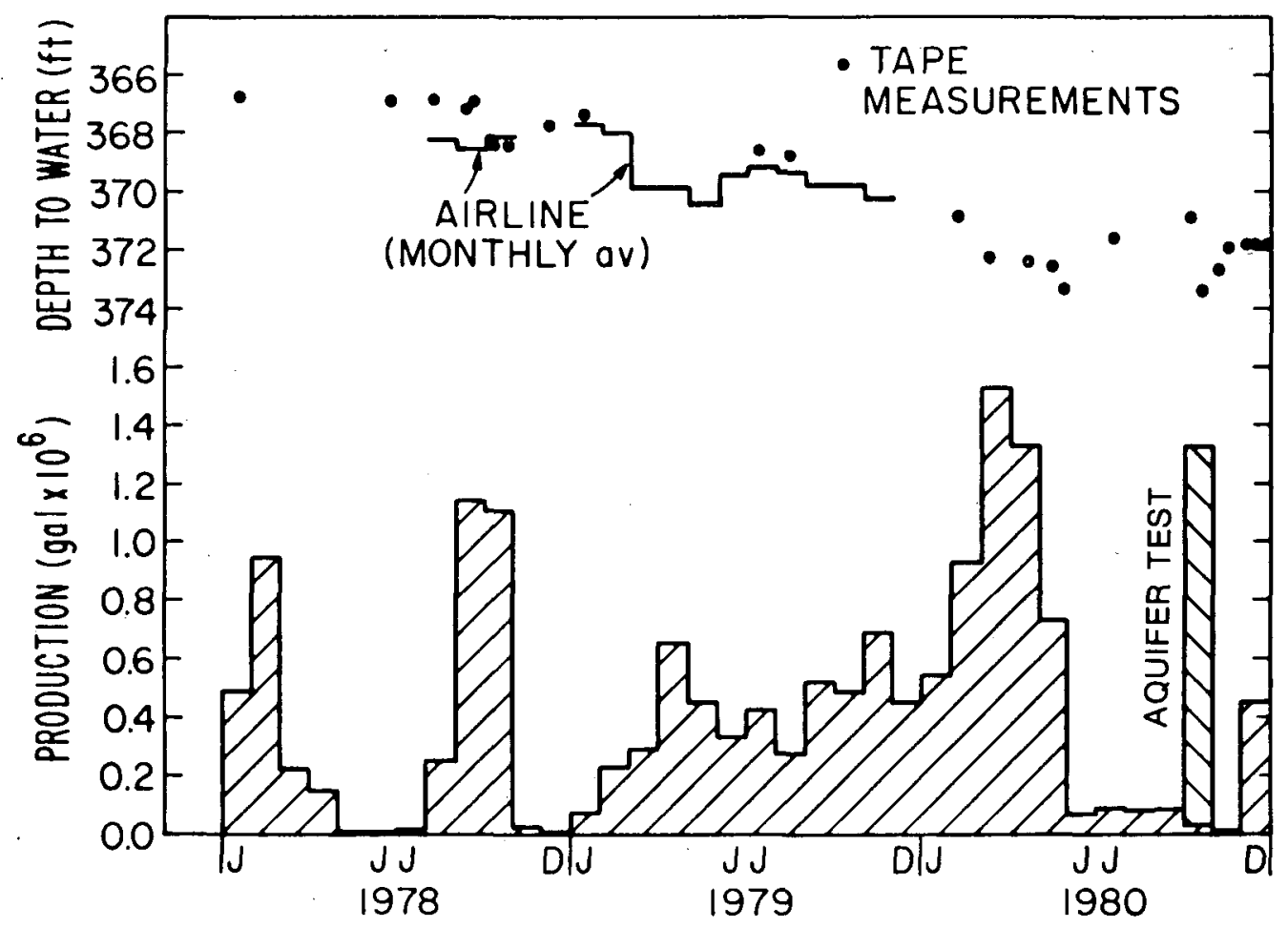

Fig. 4. Water levels and monthly production from Well FH-1, 1978-1980.

aquifer test in FH-2 and bailing tests of FH-3 were consistent with such plugging. The large (16-in.) diameter of the casing precluded cleaning out the slots by conventional methods.

Five observation holes (slim) were drilled to a depth of $450 \mathrm{ft}$ in December 1979 and January 1980 (Fig. 3). The holes are cased with 1-1/2 in. casing. ${ }^{12}$ During the drilling of the holes, no geologic or hydrologic logs were kept and the holes were not properly developed. Thus, their usefulness as observation wells is questionable.

\section{Production and Water Levels in Well FH-1}

Production from FH-1 has fluctuated a great deal since November 1976 (Fig. 4) because there has been varied demand. The water is supplied for geothermal (deep) well drilling and experiments in the system and for domestic supply onsite. During 1979 and 1980, the monthly production varied from $0.08 \times 10^{6} \mathrm{gal}$ in January 1979 to $1.54 \times 10^{6} \mathrm{gal}$ in March 1980 . The production of $1.3 \times 10^{6} \mathrm{gal}$ in October 1980 was mainly for the 10-day aquifer test. During the summer of 1980 , the production fell to under $0.1 \times 10^{6} \mathrm{gal}$ per month.
Cumulative production from $\mathrm{FH}-1$ from November 1976 through December 1980 is $20 \times 10^{6}$ gal (Fig. 5).

Water levels in the well were recorded by an airline and continuous airline recorder until November 1979 (Fig. 4). Because the water levels do not fluctuate more than $1 \mathrm{ft}$ during pumping, these airline records can only approximate long-term trends. Supplemental measurements were taken with a steel tape. Since October 1980, measurements have been made using the airline and a Wallace-Tiernan pressure gauge (accurate to about 0.02 $\mathrm{ft}$ of water). The average monthly water level has declined approximately $6 \mathrm{ft}$ since January 1978.

\section{Aquifer Evaluation by American Ground Water Consultants, Inc., Spring 1980}

During the spring and early summer of 1980, American Ground Water Consultants, Inc. (AGW) conducted an aquifer evaluation program. ${ }^{13,14}$ Their primary objective was to determine the aquifer transmissivity and storage coefficient to predict the effect on the nearby streams or rivers caused by pumping the aquifer. The following paragraphs summarize their results. 


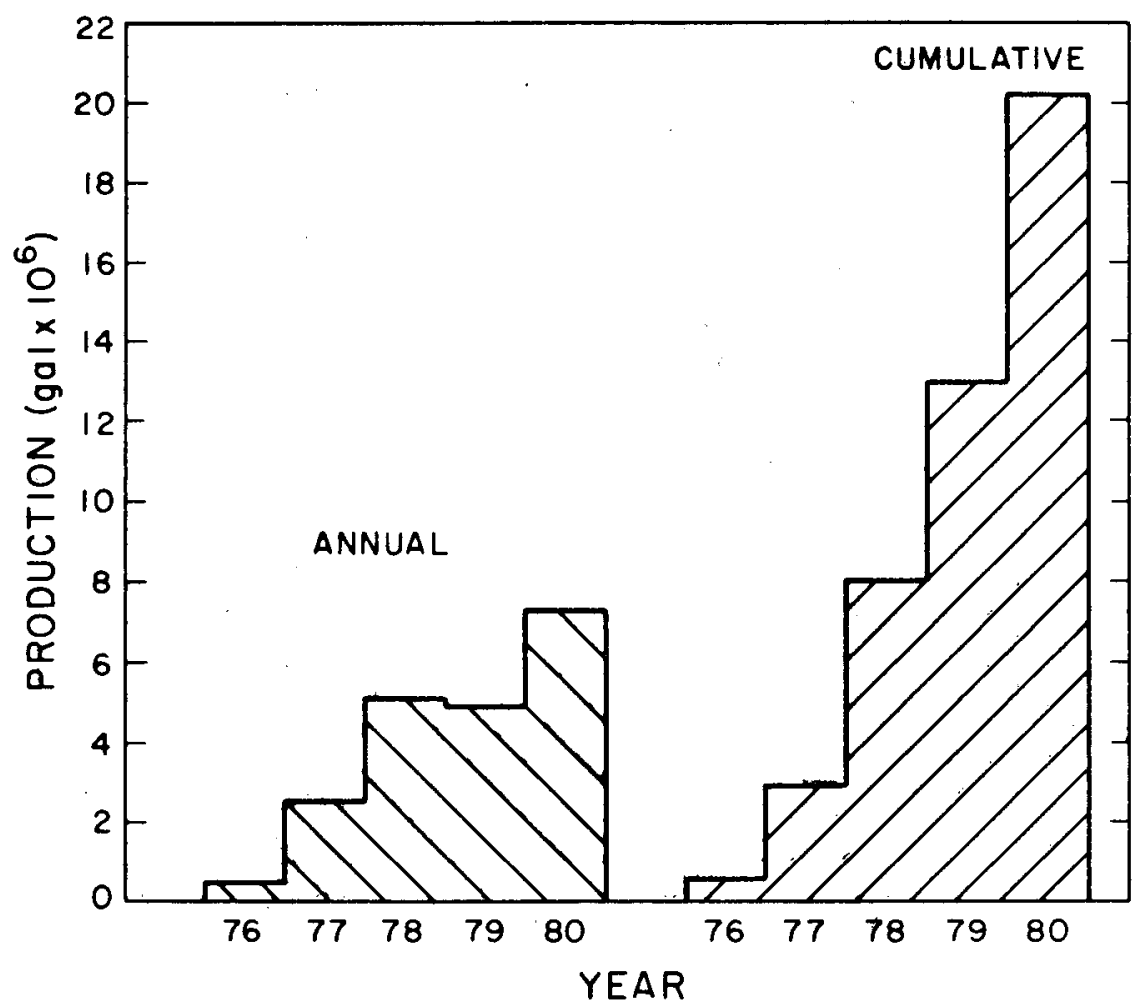

Fig. 5. Annual and cumulative production from Well FH-1, 1976-1980.

After analyzing the results of injection tests in the five slim holes, a 200-min aquifer test in $\mathrm{FH}-1$ where $\mathrm{Q}=40$ gpm, and the results of a 240 -min aquifer test in FH-2 conducted in February $1980,{ }^{12,15}$ aquifer transmissivity was determined to be $7000 \mathrm{gpd} / \mathrm{ft} .{ }^{13}$ The aquifer storage coefficient was assumed to be $1 \times 10^{-5}$, after Purtymun. ${ }^{11}$ Assuming a withdrawal rate of 10 acre-ft/yr for a 10 -yr period from the aquifer, AGW calculated a surface water depletion in the Rio Cebolla for a 20-yr period (Table II).

Later in 1980, AGW refined their results on aquifer transmissivity using a standard, two-dimensional, steady-state, finite-difference computer model for ground water flow. ${ }^{14}$ They reestimated the transmissivity to be $1740 \mathrm{gpd} / \mathrm{ft}$, and made the following assumptions: (1) the aquifer's eastern outcrop and the Virgin Canyon fault south of Fenton Hill were assumed to be impermeable boundaries, (2) streams were assumed to be in hydraulic contact with the aquifer in all locations, (3) the transmissivity and storage coefficients were assumed to be uniform throughout the aquifer, and (4) a ground water recharge (and hence soil infiltration) rate was assumed to be 200 acre- $\mathrm{ft} / \mathrm{mi}^{2}$ annually. Using this
TABLE II

EVALUATION OF STREAM DEPLETION

FROM GROUND WATER DISCHARGE TO

WELLS AT FENTON HILL

(after AGW 1980, Ref. 13)

\begin{tabular}{ccc}
$\begin{array}{c}\text { Year After } \\
\text { Discharge } \\
\text { Begins }\end{array}$ & $\begin{array}{c}\text { Surface Water } \\
\text { Depletion } \\
\text { (acre-ft/yr) }\end{array}$ \\
\cline { 1 - 1 } & & \\
1 & & 0.06 \\
5 & & 6.9 \\
10 & & 15.0 \\
20 & & 6.3
\end{tabular}

revised transmissivity, the effects on nearby stream flow by ground water pumpage were recomputed for cases of a confined and unconfined aquifer. These calculations assumed a pumping schedule of 70 acre-ft the first 10 
months, and 15 acre-ft for the following $6 \mathrm{yr}$. In a confined aquifer, the effect on the streams would reach a maximum after 5 months of pumping; $95 \%$ of the water that would otherwise replenish streamflow would be diverted. After 10 months, stream flow depletion would then equal the current pumping rate. In contrast, in an unconfined aquifer, the stream flow would be decreased by $4 \%$ of total flow after 6 yr of ground water pumping. Assumed storage coefficients of $1 \times 10^{-4}$, and $5 \times 10^{-2}$ were used for the confined and unconfined cases, respectively.

\section{AQUIFER EVALUATION BY LOS ALAMOS NATIONAL LABORATORY, FALL 1980}

During October and November 1980, the Laboratory conducted an aquifer evaluation at Fenton Hill. The purpose for this was twofold: to determine an optimal discharge rate $Q$ for the new, higher capacity pump set in FH-1 in September 1980, and to determine if the aquifer would produce the amount of water required for the next $5 \mathrm{yr}$. The evaluation consisted of both step discharge and constant discharge drawdown tests.

\section{A. Step Discharge Test}

The results of the step discharge test, conducted on October 9, 1980, indicated that the optimal discharge rate $Q$ for the $\mathrm{FH}-1$ pump would be $100 \mathrm{gpm}$, which is near the pump's design discharge limit. Pump discharge rates of $50,60,80,100$, and $108 \mathrm{gpm}$ were run in successive 60-min segments. At the end of the 5-h test, the cumulative drawdown was $0.3 \mathrm{ft}$. Five minutes after the pump was shut off, the water level returned to the pretest level. Because of the small drawdown associated with the pump's maximum rate, a $Q$ of $100 \mathrm{gpm}$ was chosen for the aquifer drawdown test.

\section{B. Drawdown Test}

An aquifer drawdown test using a constant discharge rate of $100 \mathrm{gpm}$ from well FH-1 began October 16 , 1980. The well was pumped at a constant rate until the morning of October 25 when the pump was shut off. Water level recovery was then monitored until November 12. A total of $1.3 \times 10^{6} \mathrm{gal}(4$ acre- $\mathrm{ft})$ of water was produced.
The water level in the pumping well FH-1 was measured using an airline and a Wallace-Tiernan pressure gauge. The water level in the well was also checked with a steel tape before and after the test.

During the test, wells FH-2 and FH-3 were used for observation wells. A float recorder on FH-2 recorded continuous water level changes, whereas an electrical conductivity water level indicator was used to measure the water level in FH-3. A microbarograph operated continuously during the drawdown and recovery period so that the water level data could be corrected for barometric changes using standard methods described in Ref. 16. The barometric efficiency of the aquifer was calculated to be $44 \%$, using water level and barometric data which had been collected from both heavy and light pumping periods. ${ }^{17}$

1. Transmissivity and Storage Coefficient. The water level in FH-1 declined $2.37 \mathrm{ft}$ by the end of the pumping period, October 25. By the end of the recovery period, November 12, the water level had recovered $1.19 \mathrm{ft}$. The water level declined $1.96 \mathrm{ft}$ in FH-3 and recovered approximately $1 \mathrm{ft}$ at the end of the recovery period. There was a great deal of fluctuation in FH-2 even after correction for barometric effects. The net drawdown from pumping was about $0.2 \mathrm{ft}$.

Using these water level drawdown and recovery data from FH-1 and FH-3, the transmissivity ( $T$ ) and storage coefficient (s) were computed (Table III). ${ }^{17}$ Two independent methods were used to determine the transmissivity:

1. Jacob Straight-Line Approximation. A semilogarithmic plot of drawdown versus time for FH-1 and FH-3 is used (Figs. 6 and 7). ${ }^{18,19} \mathrm{~A}$ straight line is fitted to the data and the $\mathrm{T}$ is computed over one log cycle. Latest time data were chosen for the line fits because they are considered to be most conservative and reflect the largest possible zone of influence. The transmissivity was computed to be $5000 \mathrm{gpd} / \mathrm{ft}$ for $\mathrm{FH}-1$ and 5000 $\mathrm{gpd} / \mathrm{ft}$ for $\mathrm{FH}-3$. This was repeated using the water level recovery data and a dimensionless time. The transmissivity was calculated to be $5000 \mathrm{gpd} / \mathrm{ft}$, and $5300 \mathrm{gpd} / \mathrm{ft}$ for $\mathrm{FH}-1$ and $\mathrm{FH}-3$, respectively (Figs. 8 and 9). ${ }^{18,19}$

2. Theis Nonequilibrium Formula. This classic technique uses a log-log plot of drawdown versus time. Matching an artesian, nonleaky type curve to the plot, both the transmissivity and storage coefficient can be computed. ${ }^{20}$ Using this method, with FH-3 
TABLE III

\section{TRANSMISSIVITY AND STORAGE COEFFICIENTS}

\begin{tabular}{|c|c|c|}
\hline Transmissivity & Data Well & $\underset{(\mathrm{gpd} / \mathrm{ft})}{T}$ \\
\hline Residual Drawdown & $\mathrm{FH}-1$ & 5000 \\
\hline \multirow{3}{*}{ Straight Line Solution (SLS) } & FH-3 & 5000 \\
\hline & FH-1 (recovery) & 5000 \\
\hline & FH-3 (recovery) & 5300 \\
\hline Theis Nonequilibrium Formula & FH-3 & 2100 \\
\hline
\end{tabular}

Storage Coefficient

(Dimensionless)

Residual Drawdown, SLS

FH-3

$6.5 \times 10^{-2}$

Theis Nonequilibrium Formula

FH-3

$7.5 \times 10^{-2}$

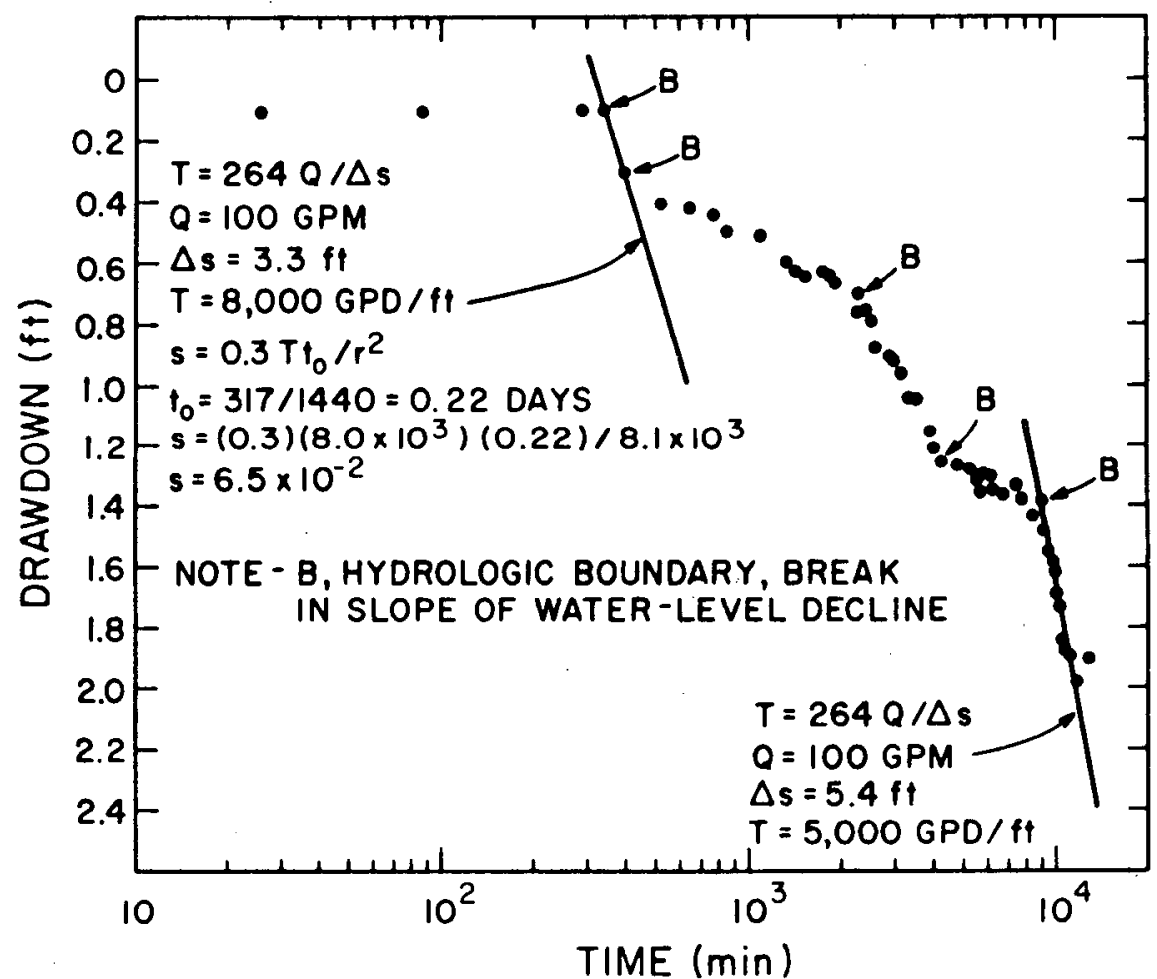

Fig. 6. Water level drawdown in Well FH-3 during pumping, October 16-25, 1980. 


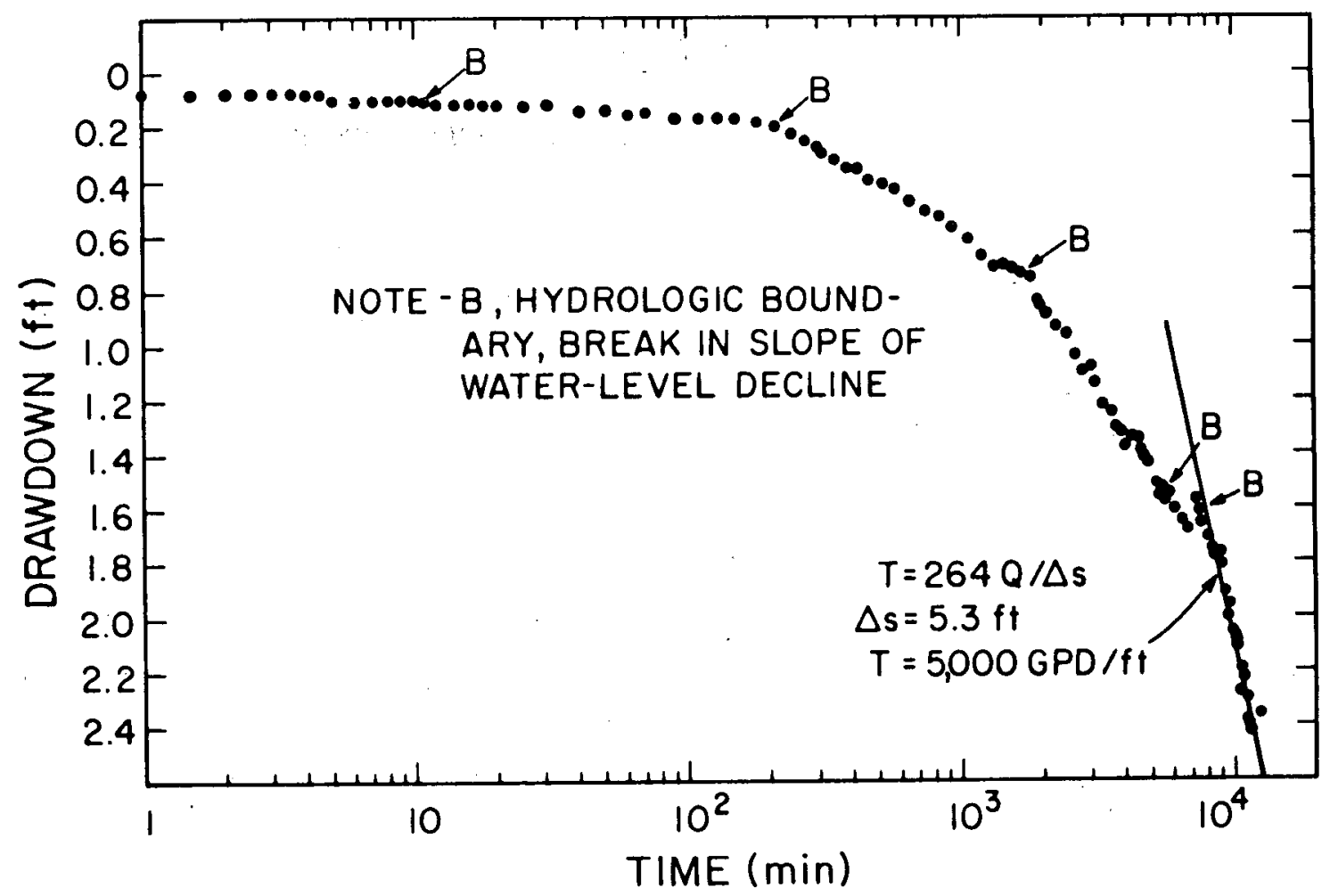

Fig. 7. Water level drawdown in Well FH-1 during pumping, October 16-25, 1980.

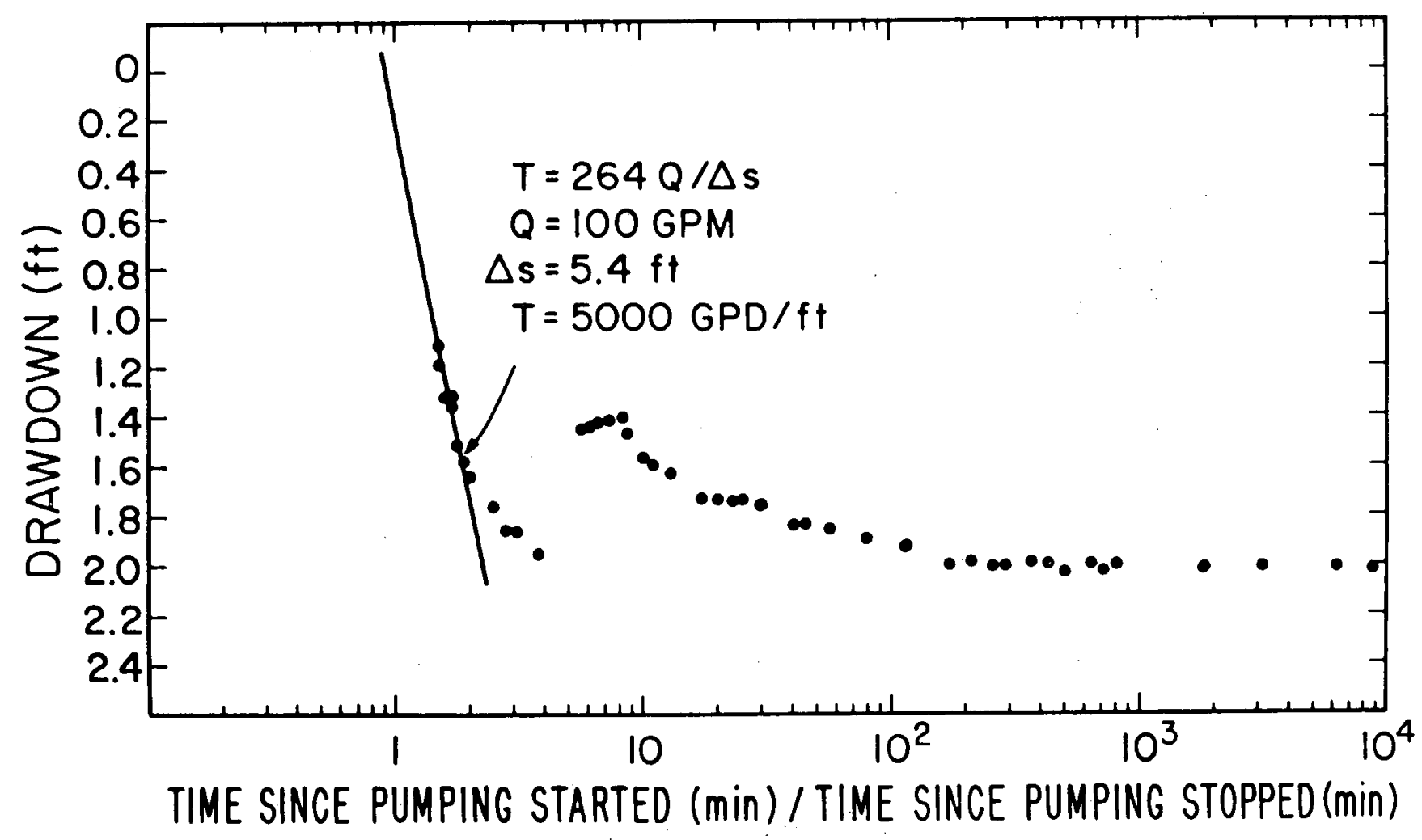

Fig. 8. Water level recovery in Well FH-1 after pumping ended, October 25-November 12, 1980. 


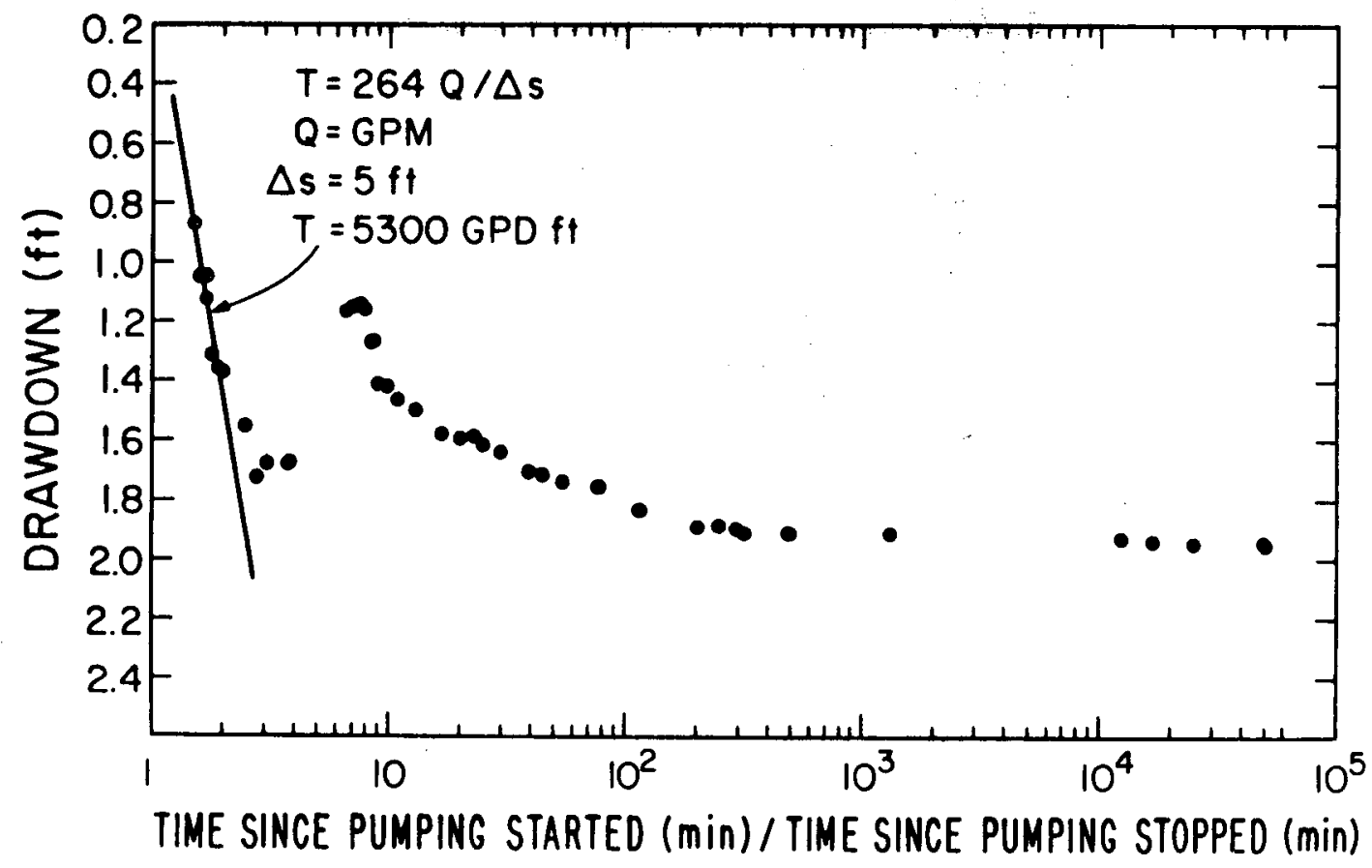

Fig. 9. Water level recovery in Well FH-3 after pumping ended, October 25-November 12, 1980.

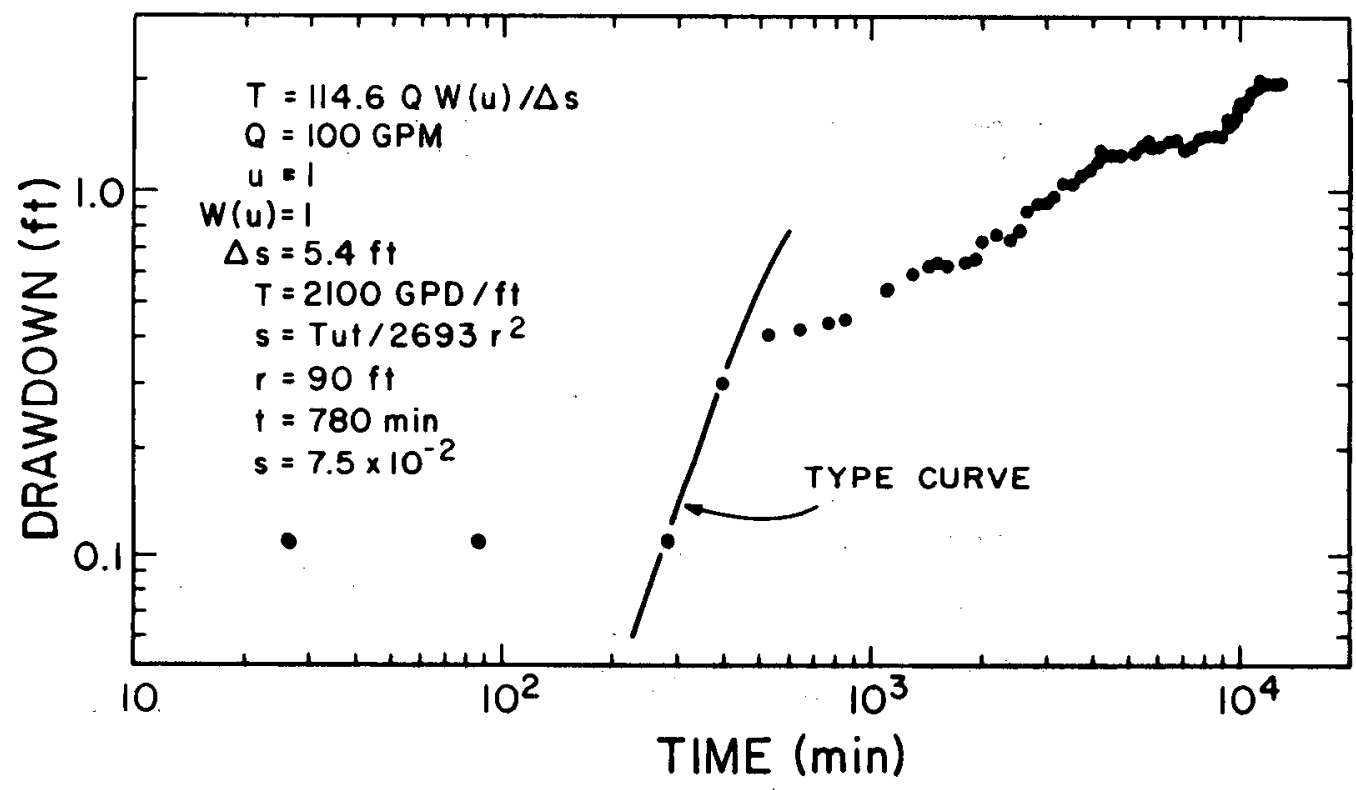

Fig. 10. Nonleaky-type curve solution based on drawdown of water levels in Well FH-1.

data fitted to the early time drawdown before any indication of interferences, a $\mathrm{T}$ of $2100 \mathrm{gpd} / \mathrm{ft}$ was computed (Fig. 10).

Two methods were used to determine the storage coefficient, the residual drawdown straight-line solution, and the Theis nonequilibrium formula using the type curve.
1. Residual Drawdown Straight-Line Solution. The straight-line portion of the curve in the Jacob Straight-Line Approximation is used to find the time where the drawdown is zero, $t_{0}$. Using the computed transmissivity and the distance $r$ between 
the pumping well and the observation well, the storage coefficient $\mathrm{s}$ may be determined by $\mathrm{s}=$ $0.3 \mathrm{Tt}_{\mathrm{o}} / \mathrm{r}^{2}$, where the units are $\mathrm{gpd} / \mathrm{ft}$, days, and $\mathrm{ft}$, respectively. An s of $6.5 \times 10^{-2}$ was obtained from the FH-3 data. ${ }^{19,21}$

2. Theis Nonequilibrium Formula Using the Type Curve. A $\log -\log$ plot of drawdown versus time was prepared using the data from FH-3 and fit to a nonleaky artesian aquifer type curve. Using the standard formula, $s=T u t / 2693 r^{2}$, where $u$ is the argument of the well function, $s$ was computed to be $7.5 \times 10^{-2}$. The type curve was fit using the early time data because there were interferences during the later stages. ${ }^{20}$

Averaging the results from these methods, the aquifer has a transmissivity of about $5000 \mathrm{gpd} / \mathrm{ft}$ and a storage coefficient of 0.07 (Table III).

2. Discussion of the Values of Transmissivity and Storage Coefficient. As described earlier, the aquifer was artesian when it was first penetrated in 1976-the water rose about $10 \mathrm{ft}$ above the top of the saturated section. With continued removal of water, the potentiometric surface of the aquifer will decline until it falls below the top of the saturated section, and the aquifer will then behave as an unconfined, or water table, aquifer. However, pumping of $\mathrm{FH}-1$ results in an almost instantaneous response in water level decline in FH-3 indicating the aquifer is still under artesian pressure.

The computed values for transmissivity and storage coefficient were checked by computing drawdowns and comparing them to the measured drawdowns of 19761980. The Theis nonequilibrium formulas for radial flow in a confined aquifer were applied using superposition to compute the drawdown in $\mathrm{FH}-1$, along with the known annual discharge volumes for the years 1976-1980 (Fig. 5). Values of $T=5000 \mathrm{gpd} / \mathrm{ft}$ and $\mathrm{s}=0.07$ were used, and the drawdown at FH-1 was computed to be $5.7 \mathrm{ft}^{22}$ This is compared to a measured $6 \mathrm{ft}$ of drawdown over the same period of time. This close agreement between computed and measured drawdown infers one or both of these conclusions; first, the computed values for the transmissivity and storage coefficient must be in the proper (actual) range, and second, the assumption that the aquifer is still confined is valid. The Laboratory determined transmissivity ( $\mathrm{T}=5000 \mathrm{gpd} / \mathrm{ft}$ ) value is of comparable magnitude to those obtained by AGW using a different method ( $\mathrm{T}=1740$ to $7000 \mathrm{gpd} / \mathrm{ft}$ ).
3. Ground Water Boundaries. During the drawdown portion of the aquifer test, considerable interference of ground water flow toward the well was apparent with the changes in slope of water levels when plotted against time (Figs. 6 and 7). This interference took place during both drawdown and recovery phases.

The water level drawdown of $\mathrm{FH}-1$ and $\mathrm{FH}-3$ indicated no barriers between the two wells. The first barrier appeared at accelerated drawdown in FH-1 at $200 \mathrm{~min}$ and $\mathrm{FH}-3$ at $350 \mathrm{~min}$ after pumping began (Figs. 6 and 7). The drawdown data of FH-1 and FH-3 during the 10-day test indicate as many as five boundaries in the aquifer. These boundaries reflect the channels cut in the Abo formation, as previously described. From the number of boundaries intercepted, it may be deduced that the aquifer is limited in its spatial extent. It is highly probable that with continued pumping, more barriers will become apparent and accelerated water level declines will occur in $\mathrm{FH}-1$.

\section{PROJECTED AQUIFER RESPONSE TO FUTURE PUMPING}

A water usage schedule for $5 \mathrm{yr}$ of operation of the Phase II system has been formulated (Table IV). ${ }^{23}$ Water level decline due to this pumping in FH-1 (assumed pumping well) and FH-3 (90 ft from FH-1) has been calculated over the same time frame (Table V). The Theis

TABLE IV

\section{PROJECTED WATER ÚSE FROM 1981 THROUGH 1985}

\begin{tabular}{lrrr} 
Year & & $\begin{array}{c}\text { Annual } \\
\text { Usage } \\
\text { (gal) }\end{array}$ & $\begin{array}{r}\text { Annual } \\
\text { Usage } \\
\text { (acre-ft) }\end{array}$ \\
\cline { 1 - 1 } 1981 & & $6 \times 10^{6}$ & 18.41 \\
1982 & & $13 \times 10^{6}$ & 39.90 \\
1983 & & $30 \times 10^{6}$ & 92.07 \\
$\frac{1984 \text { and } 1985}{\text { Total }}$ & $\frac{113 \times 10^{6}}{162 \times 10^{6}}$ & $\frac{346.81}{497.19}$
\end{tabular}


TABLE V

WATER LEVEL DECLINE AT FH-1 AND FH-3

\begin{tabular}{|c|c|c|}
\hline Year & $F H-1(f t)$ & FH-3 (ft \\
\hline 1981 & 4.2 & 1.8 \\
\hline 1982 & 9.2 & 4.1 \\
\hline 1983 & 21.3 & 9.5 \\
\hline 1984 & 40.3 & 18.2 \\
\hline 1985 & 41.6 & 19.4 \\
\hline
\end{tabular}

nonequilibrium equations together with superposition were used to determine the ground water decline. ${ }^{20,24}$ The transmissivity and storage coefficients derived from the 1980 aquifer test were used in these computations. After $5 \mathrm{yr}$ of pumping, a decline of approximately $42 \mathrm{ft}$ of water in FH-1 and $20 \mathrm{ft}$ in FH-3 was computed.

These calculations are nonconservative in that they do not account for any additional impermeable aquifer boundaries that may be encountered during pumping. Geologic information is not presently available to be able to project such effects in the calculation. It would be likely for boundaries to appear because the aquifer is apparently spatially limited. The effect of additional impermeable boundaries would be a more rapid lowering and greater decline of the water level in all wells onsite. It is clear that withdrawal to date had exceeded recharge to the aquifer because the water level has declined $6 \mathrm{ft}$ since January 1978. From the aquifer test performed in October 1980, it is also apparent that ground water is being depleted: since the removal of $1.3 \times 10^{6} \mathrm{gal}$, the water table has not returned to pretest levels.

If pumping in the future is sufficient to deplete aquifer to the point where it behaves under water-table (unconfined) conditions, then drawdown would also be greater than that projected by these computations.

\section{CHEMICAL QUALITY}

Water from the well FH-1 was analyzed for chemical and radiochemical constituents to compare with standards set for municipal or domestic use by the U.S. Environmental Protection Agency and State of New Mexico standards. ${ }^{25,26} \mathrm{~A}$ comparison of the analytical results
TABLE VI

\section{CHEMICAL AND RADIOCHEMICAL CONCENTRATIONS IN WATER FROM SUPPLY WELL FH-1, 1979}

\begin{tabular}{|c|c|c|}
\hline Chemical $(\mathrm{mg} / \ell)$ & $\begin{array}{c}\text { Supply Well } \\
\text { FH-1 }\end{array}$ & $\begin{array}{c}\text { Standard or } \\
\text { Criteria }^{\mathrm{a}}\end{array}$ \\
\hline $\mathbf{A g}$ & $<0.001$ & 0.05 \\
\hline As & $<0.001$ & 0.05 \\
\hline $\mathbf{B a}$ & $<0.5$ & 1.0 \\
\hline $\mathrm{Cd}$ & $<0.01$ & 0.010 \\
\hline $\mathrm{Cl}$ & 19 & 250 \\
\hline $\mathrm{Cr}$ & $<0.002$ & 0.05 \\
\hline $\mathbf{F}$ & 0.3 & 2.0 \\
\hline $\mathrm{Hg}$ & $<0.0005$ & 0.002 \\
\hline $\mathrm{NO}_{3}$ & 1.5 & 45 \\
\hline $\mathrm{Pb}$ & 0.002 & 0.05 \\
\hline $\mathrm{Se}$ & 0.005 & 0.01 \\
\hline TDS & 244 & 1000 \\
\hline
\end{tabular}

Radiochemical (pCi/ $)$

$\begin{array}{lcr}{ }^{3} \mathrm{H} & <0.6 & 20 \\ { }^{137} \mathrm{Cs} & <80 & 200 \\ { }^{238} \mathrm{Pu} & <0.03 & 15 \\ { }^{239} \mathrm{Pu} & <0.04 & 15 \\ { }^{\text {Gross alpha }} & 2.3 & 15 \\ \text { Total U } & 1.9 & 1800\end{array}$

${ }^{\mathrm{a}}$ References 25 and 26.

of water from the well to federal and state standards show that the water is below limits set for municipal use (Table VI). ${ }^{27}$

During the 10-day aquifer test, water samples collected at frequent time intervals were analyzed to determine if changes occurred with production. Of the nine samples analyzed, the major constituents, calcium, sodium, chloride, bicarbonate, and TDS, varied slightly from one sample to another, but showed no significant change during the test (Fig. 11). The variations in concentrations were within the range of analytical error. Water temperature during the test remained constant at $27^{\circ} \mathrm{C}$. 


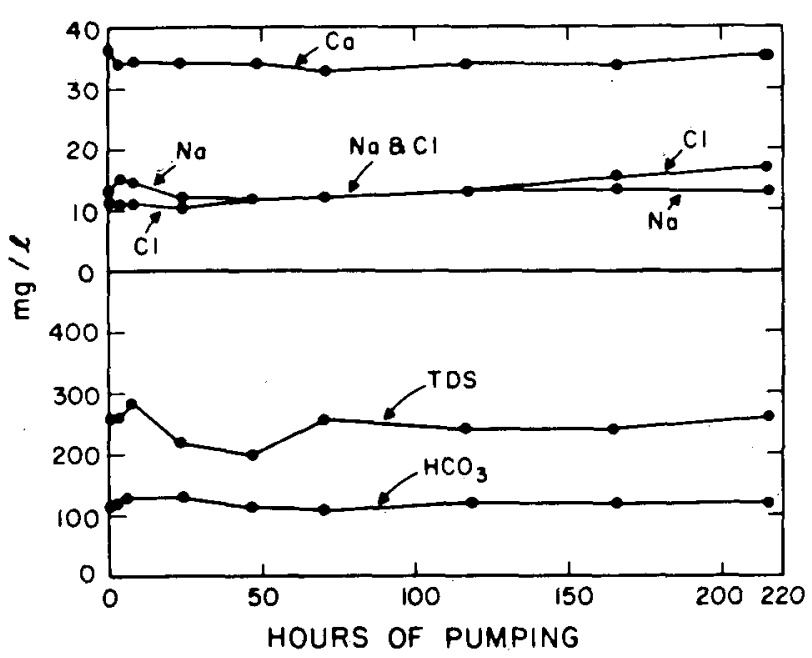

Fig. 11. Select chemical constituents in water from Well FH-1 during aquifer test, October 16-25, 1980.

\section{SUMMARY}

1. The main potable aquifer at Los Alamos National Laboratory's Fenton Hill Geothermal Site is in the lower part of the Paliza Canyon Formation and the Abiquiu Tuff, which is a friable, tuffaceous sandstone $90 \mathrm{ft}$ thick at the site.

2. A 10-day aquifer test was performed during October and November 1980. Measurements were taken from one pumping well and two observation wells. Results indicate that the aquifer has a transmissivity of about $5000 \mathrm{gpd} / \mathrm{ft}$ and a storage coefficient of about 0.07 .

3. These values for transmissivity and storage coefficient were checked by using them to predict drawdown at FH-1 from 1976 through 1980 and comparing the predicted drawdown with that measured. The predicted and measured drawdown agreed to within $5 \%$ error.

4. Aquifer test results also indicate a number of impermeable, hydrologic boundaries. It is clear that the aquifer is limited spatially, and likely that more boundaries will become apparent with continued pumping.

5. From a withdrawal of 500 acre-ft over 5 yr (Table IV) from the aquifer, it was calculated that the water level in pumping well $\mathrm{FH}-1$ will decline a minimum of nearly $42 \mathrm{ft}$; however, due to the presence of ground water boundaries, the water level decline will be much greater and may result in depletion of the aquifer.

6. The chemical quality of the aquifer water has remained essentially constant from 1976 through 1980.

7. The aquifer in the Abiquiu Tuff was artesian when originally drilled. The aquifer discharges generally to the southwest in Lake Fork Canyon in a series of seeps and springs. The top of the aquifer is relatively flat at the site.

8. The step discharge test indicated that the aquifer could produce $100 \mathrm{gpm}$ with minimum drawdown.

9. Cumulative water production from the aquifer from November 1976 through December 1980 is $20 \times 10^{6}$ gal.

\section{REFERENCES}

1. Hot Dry Rock Program Staff, "Hot Dry Rock Geothermal Energy Development Program, Annual Report-Fiscal Year 1979," Los Alamos Scientific Laboratory report LA-8280-HDR (1980).

2. W. E. Hale, L. J. Reiland, and J. P. Beverage, "Characteristics of Water Supply in New Mexico," New Mexico State Engineering Tech report 31 (1965).

3. R. L. Smith, R. A. Bailey, and C. S. Ross, "Structural Evolution of the Valles Caldera, New Mexico, and Its Bearing on Emplacement of Ring Dikes," U.S. Geol. Sur. Prof. Paper 424-D (1961).

4. C. S. Ross, R. L. Smith, and R. A. Bailey, "Outline of Geology of the Jemez Mountains, New Mexico," New Mexico Geol. Soc. Twelfth Field Conf., Albuquerque, New Mexico (1961).

5. R. A. Bailey, R. L. Smith, and C. S. Ross, "Stratigraphic Nomenclature of the Volcanic Rocks in the Jemez Mountains, New Mexico," U.S. Geol. Sur. Bull. 1274-P (1969).

6. R. L. Smith, R. A. Bailey, and C. S. Ross, "Geologic Map of the Jemez Mountains, New Mexico," U.S. Geol. Sur. Misc. Geol. Inv. Map I-571 (1970). 
7. W. D. Purtymun, F. G. West, and R. A. Pettitt, "Geology of Geothermal Test Hole GT-2, Fenton Hill Site, July 1974," Los Alamos Scientific Laboratory report LA-5780-MS (Novèmber 1974).

8. W. D. Purtymun, "Geology of the Jemez Plateau West of the Valles Caldera," Los Alamos Scientific Laboratory report LA-5124-MS (February 1973).

9. W. Purtymun and F. West, "Exploratory Test Hole in Volcanics with Possible Completion as a Small Yield Water Supply," Los Alamos Scientific Laboratory memorandum H8-74-140 to M. Smith (April 2, 1974).

10. N. Becker and W. Purtymun, "Hydrologic Data Related to Supply Well FH-1, FH-2, and FH-3 at TA-57," Los Alamos Scientific Laboratory memorandum G-5/H-8 to Distribution (June 23, 1980).

11. W. Purtymun, "Hydrologic Characteristics of Supply Well FH-2," Los Alamos Scientific Laboratory memorandum H8-80-247 to N. Becker and D. Miles (April 4, 1980).

12. W. Purtymun, N. Becker, and D. Miles, "Water Supply at Fenton Hill," Los Alamos Scientific Laboratory memorandum H8-80-184 to Distribution (March 12, 1980).

13. American Ground Water Consultants, Inc., "Hydrogeology of the Hot Dry Rock Site at Fenton Hill, Sandoval County, New Mexico," Submitted to Los Alamos Scientific Laboratory (June 1980).

14. American Ground Water Consultants, Inc., "Results of Ground Water Model Studies at Fenton Hill, Sandoval County, New Mexico," Submitted to Los Alamos Scientific Laboratory (July 1980).

15. Dan Miles, "Pumping Test on Water Well \#2," Los Alamos Scientific Laboratory memorandum G-4 to G. Nunz, Morris, and Purtymun (Feb. 5, 1980).

16. Bureau of Reclamation, "Ground Water Manual," U.S. Government Printing Office, Washington, D.C. (1977).
17. W. C. Ballance, N. M. Becker, and W. D. Purtymun, "Pumping Test of Well FH-1, Fenton Hill, October 16-November 12, 1980," Los Alamos National Laboratory report (in preparation).

18. L. K. Wenzel, "Methods for Determining Permeability of Water-Bearing Materials," U.S. Geol. Sur. Water-Supply Paper 887 (1942).

19. R. H. Brown, "Selected Procedures for Analyzing Aquifer Test Data," Am. Water Works Assoc. J. 45, No. 8 (1953).

20. C. V. Theis, "The Relation Between the Lowering of the Piezometric Surface and the Rate and Duration of Discharge of a Well Using Ground-Water Storage," Am. Geophys. Union Trans. (1935).

21. Jack Bruin and H. E. Hudson, Jr., "Selected Methods for Pumping Test Analysis," Illinois State Water Survey, Report of Investigation 25, third printing (1961).

22. N. Becker, "Computation of Drawdown at FH-1 Using Superposition," Los Alamos National Laboratory memorandum H8-81-309 to W. D. Purtymun (May 15, 1981).

23. H. N. Fisher, "Water Losses for Phase II System: 1981 Though 1985," Los Alamos Scientific Laboratory memorandum G-6 to J. Hill and R. W. Spence (Dec. 9, 1980).

24. D. K. Todd, "Ground Water Hydrology," John Wiley and Sons, Inc., New York (1959).

25. U.S. Environmental Protection Agency, "National Interim Primary Drinking Water Regulations," EPA-570/9-76-003, Environmental Protection Agency, Office of Water Supply (1976).

26. New Mexico Environmental Improvement Department, "Water Supply Regulations," New Mexico Environmental Improvement Department, Santa Fe, New Mexico (1977).

27. W. Purtymun, R. W. Ferenbaugh, A. K. Stoker, and W. H. Adams, "Water Quality in the Vicinity of Fenton Hill, 1979," Los Alamos Scientific Laboratory report LA-8424-PR (1980). 